\title{
Parametric Evaluation of Deaf Students' Comprehension and Skills
}

\author{
Zainuddin Ibrahim, Norlidah Alias, and Abu Bakar Nordin
}

\begin{abstract}
The purpose of this study is to identify the effectiveness of graphic design learning module based on technology and deaf student learning styles towards deaf students' comprehension and skills using parametric test. Deaf students require a different learning approach compared to normal students in ensuring their mastery in specific skills. Undoubtfully, sign language has become an impediment in dilevering message when some teachnical terms were not able be interpreted to sign language. The available language interpreters are on voluntary basis and are restricted to time, distant location and skills. To add to this, deaf student have weak memory to remember the lesson. In evaluating them, quiz has been used to evaluate their understanding through parametric testing paired sample t test. While project-type assignment has been used to evaluate skills through parametric testing one sample $t$ test. Findings of the study a significant difference in pretest $($ mean $=15.54, S . D=1.989, n=15)$ and posttest $($ mean $=78.15$, S.D $=2.832, n=15$ ) for all topics. Subsequently, posttest towards project shows significant difference on skills achievement $(t(15)=23.822, p<$. 05) especially on high inference value campared to others topics. In conclusions, parametric testing proves that graphic design learning module based on technology and deaf student learning styles towards deaf student comprehension and skills are significant.
\end{abstract}

Index Term-Parametric, graphic design, deaf students, technology, learning styles.

\section{INTRODUCTION}

Hearing disabilty was categorized as difficulties in hearing and deaf. If someone was not able to hear at all, he/she will be categorized as deaf [1]. Level of hearing is measured by desibel $(\mathrm{dB})$. Level of hearing for typical people is around $60 \mathrm{~dB}$ to $65 \mathrm{~dB}$ [2]. In Malaysia, approximately one percent from total population is disable people $(387,149$ people) [3]. Currently, average Malaysians registered as Malaysia Sign Language users is $55000(0.2 \%)$ people [4]. Still, Malaysia has a lower deaf population compared to other Asean countries like Indonesia 2 million (1\%) and Japan 7 million $(5.5 \%)$. However, Malaysia is higher than others Asean countries like Thailand 54 thousand $(0.1 \%)$, Taiwan 30 thousand $(0.1 \%)$, Sri Lanka 12 thousand $(0.1 \%)$ and

Manuscript received November 19, 2015; revised January 7, 2016. This work was supported in part by the Ministry of Higher Education Malaysia.

Zainuddin Ibrahim is with the Universiti Teknologi MARA, Malaysia (e-mail: macintag_01@salam.uitm.edu.my).

Norlidah Alias was with University of Malaya, Malaysia. She is now with the Department of Curriculum and Instructional Technology, Education, Malaysia (e-mail: drnorlidah@um.edu.my).

Abu Bakar Nordin is with the University of Malaya, Malaysia (e-mail: a_bakarnordin@um.edu.my).
Singapore 3 thousand $(0.1 \%)$. In the developing countries, existing deaf people will give impact to the economy. This happend when children did not get proper education [1]. According to [5] research, the programs on Information Communication Technology (ICT) like web design, animation and multimedia aplication have attracted many deaf students. All these programs are part of graphic design program fields [6]. Even though Malaysia have some higher education institutions that offer graphic design programs, but the special learning approach for the deaf students is still less. According to the deaf students' blog dan interview, deaf students face problems in their learning in higher institution [7]. Graphic design is combination of two important core elements which are comprehension and skills. Mastery of these aspects are relevant to produce competant graphic designers. However, this requires practices to ensure their cognitive functions accurately [6], [8]. Therefore, deaf students required different learning approach compared to normal students. Past research show that the deaf students have dificulties in learning because of the learning method does not meet their learning styles. Hence, it is important to indentify the uniqueness of deaf students learning styles to achieve meaningful learning [9]-[12]. In addition, past research have proven that teaching with prefered deaf students learning styles will enhance the effectiveness and motivations [13]. On the other hand, communication is another problem faced by deaf students. According to [14], it is estimated that $25 \%$ deaf students' achievement is influenced by age, language and others exclude different learning styles. Research conducted by [15] highlighted the importance of digital sign language for communication in deaf learning. Besides, [16] mentioned that deaf students have a very limited memory compared normal students. Therefore, instead of solely relying on sign language, information in visuospatial form is recommended [17], [18]. In short, the purpose of the current study is to use parametric test to evaluate the comprehension and skills of the deaf students after the implementation of graphic design learning module based on technology and deaf learning styles.

\section{LEARNING MODULE}

In this research, graphic design module based on technology and deaf learning styles was used. The module contains 5 topic which are developed through adaptation of instructioanal model [19], [20] and Waterfall model by [21]. The end module is equipped with video learning and is developed by construct communication model [22] for bi-language by combining sign language and texts. This module is also complemented with learning according to deaf 
students learning styles. In doing so, they are required to identify their own learning styles through administration of the online instrument in the module. Then, students need to follow the instruction according to the their learning styles to study these five topics.

\section{PARAMETRIC TEST}

Parametric test constitutes of valid statistic evaluation which is based on mean and standard deviation for normal distrubution data [23]. However, if data distribution is abnormal then nonparametric test will be used [statistic book]. This reasearch used t test as one of the parametric tests. Different $t$ test will be use based on the sample. Paired sample $\mathrm{t}$ test have been used for deaf students comprehension evaluation because there have two sample of pretest and posttest. While one sample $t$ test has been use for deaf students skills evaluation because only have one posttest.

\section{Methodology}

This research employs exploratory experimental research design to evaluate deaf students' comprehension and skills. Researchers focus on formative evaluation because the improvement is necessary to identify the quality of graphic design module requirements. According to [24], a module needs to be improved in achieving significant results. In this module, the deaf student will learn all five topics, namely introduction of graphic animation, graphic animation framework, graphic animation composition, making graphic animation and graphic animation documentation. This module is developed to promote student-centered learning. Thus, the students will learn independently without any help from instructors. However, the students still have freedom to seek assistance from the instructors if necessary.

Pretest on deaf students comprehension in all topics was administered using online quiz in the module. Pretest quiz was conducted before the students learn the 5 topics available in the graphic design module based on technology and deaf learning styles. Each topic has 10 questions and students have 10 minutes to answer each topic given. After completed the lesson, deaf students required to sit for a posttest. The same questions were asked but in random order. The purpose of the posttest is to compared the comprehension of deaf student after completing the lesson. The researchers run the normality testing to ensure the data was normally distributed. Then, paired sample $t$ tests were use to analyse the pretest and posttest by comparing the mean, standard daviation and $t$ value.

For the evaluation of skills, deaf students need to complete one assignment for each topic. They were given one week to complete the task and uploaded into graphic design module submission page for each topic. All assignments were evaluated by the appointed instructor. After running the normality testing, one sample t test was used to analysed the data and to see the deaf students achievement.

\section{SAMPLES}

All fifteen deaf students from graphic design program at
Ibrahim Sultan Polytechnic, Johor Baharu were selected through purposive sampling technique. Reseachers followed the research procedur by asking permission from Ministry of Education Malaysia to conduct this study. Parental consent was a priority to this study and was obtained first. The students were not divided into different groups as advised by the institution regarding sensitive issue.

\section{FINDINGS}

\section{A. Normality Test for Pretest and Posttest}

Normality testing was run tu sure the data were normally distributed. The result shows $(p<.05)$ [25], [26] and Q-Q plots are normal by male and female with Skewness 0.551 (SE $=0.752)$ and Kurtosis $-0.665(\mathrm{SE}=1.481)$ for male and Skewness 1.245 $(\mathrm{SE}=0.913)$ and Kurtosis $0.947(\mathrm{SE}=2.00)$ for female. The $\mathrm{z}$-scores value indicated confident intervals in the range of $(-1.96 \leq z \geq 1.96)$. The $z$-scores value indicate confident intervals in the range of $(-1.96 \leq z \geq 1.96)$. Below in Fig. 1 and Fig. 2 are Q-Q plots for the pretest on comprehension.

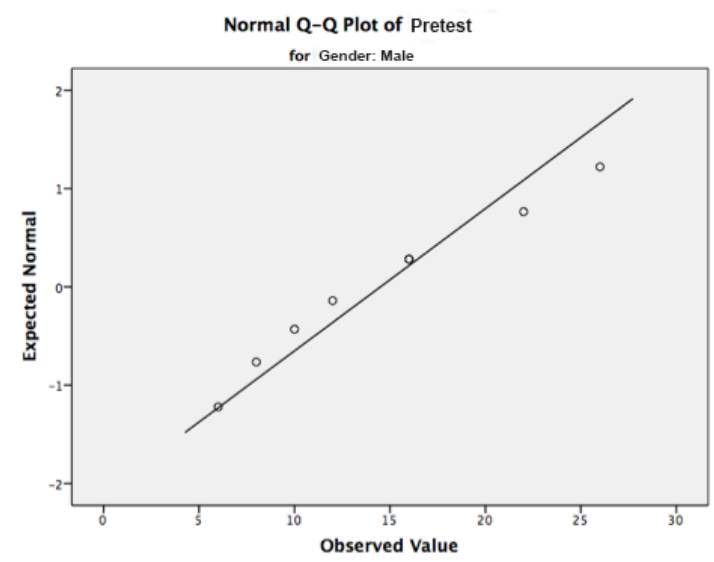

Fig. 1. Q-Q plots of pretest for male.

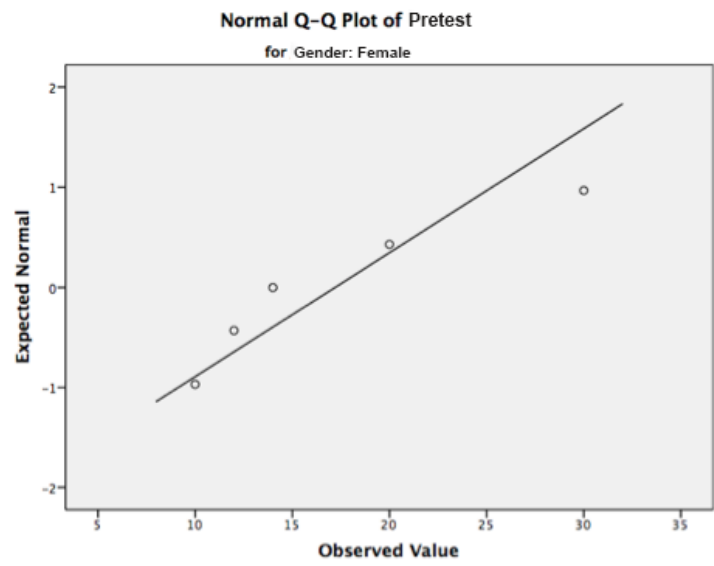

Fig. 2. Q-Q plots of pretest for female.

For the normality testing on posttest, the $\mathrm{p}$ value is significant where $(p<.05)$ [25], [26] and Q-Q plots are normal for male and female with the Skewness 0.307 (SE = 0.752 ) and Kurtosis $-0.815(\mathrm{SE}=0.550)$ for male and Skewness 0.821 $(\mathrm{SE}=0.913)$ and Kurtosis $-0.424(\mathrm{SE}=$ 2.000) for female. The $\mathrm{z}$-scores value indicate confident intervals in the range of $(-1.96 \leq z \geq 1.96)$. Below are Fig. 3 and Fig. 4 the Q-Q plots for the posttest on comprehension. 


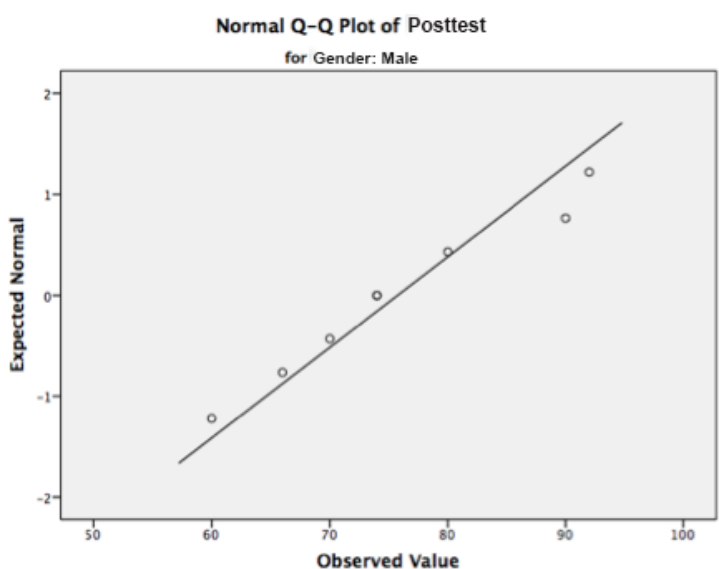

Fig. 3. Q-Q plots of posttest for male.

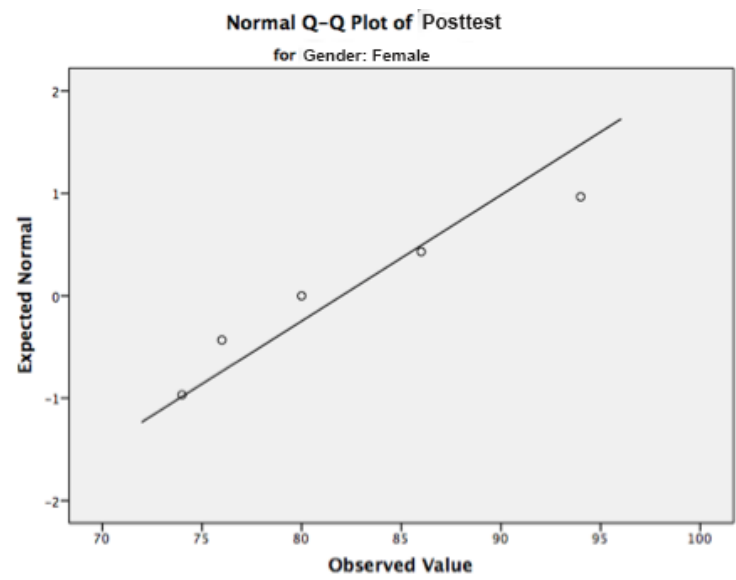

Fig. 4. Q-Q plots of posttest for female.

\section{B. Pretest and Posttest on Comprehension Evaluation}

Next is disscussion on results of pretest and posttest statistic score. The findings showed a positive improvement on the deaf students comprehension achievement. Majority of the deaf students indicated higher mean on posttest compared to pretest for each topics.

TABLE I: DESCRIPTIVE STATISTIC, MEAN AND STANDARD DEVIATION PRETEST AND POSTTEST ON INTRODUCTION TO GRAPHIC ANIMATION

\begin{tabular}{llll}
\hline \hline & Mean & $N$ & $\begin{array}{l}\text { Standard Deviation } \\
\text { (S.D) }\end{array}$ \\
Posttest & 13.077 & 15 & 2.660 \\
Pretest & 1.540 & 15 & 1.450 \\
\hline \hline
\end{tabular}

Table I indicates mean and standard deviation value between pretest and posttest for introduction of graphic animation topic. Posttest showed positive improvement in mean and $\mathrm{sd}(M=1.540, \mathrm{SD}=1.450)$ from pretest in mean and $\mathrm{sd}$ (mean $=13.077, \mathrm{~S} . \mathrm{D}=2.660, n=15)$. This show significant achievement after using the graphic design module based on technology and deaf learning styles.

TABLE II: DESCRIPTIVE STATISTIC, MEAN AND StANDARd DEVIATION PRETEST AND POSTTEST ON GRAPHIC ANIMATION FRAMEWORK

\begin{tabular}{llll}
\hline \hline & Mean & $N$ & $\begin{array}{l}\text { Standard Deviation } \\
\text { (S.D) }\end{array}$ \\
Posttest & 15.384 & 15 & 2.218 \\
Pretest & 3.077 & 15 & 1.320 \\
\hline \hline
\end{tabular}

Based on Table II, the mean in pretest is 3.077 and posttest 15.384 for the graphic animation framework topic. This figure shows positive improvement from pretest of (mean=3.077,
$\mathrm{S} . \mathrm{D}=1.320, n=15)$ to posttest of (mean $=15.384$, S.D = $2.218, n=15$ ). Meaning that deaf students show a significant improvement after using the graphic design learning module.

TABLE III: DESCRIPTIVE STATISTIC, MEAN AND STANDARD DEVIATIONFORPRETEST AND POSTTESTON GRAPHIC ANIMATION

\begin{tabular}{llll}
\multicolumn{3}{c}{ COMPOSITION } \\
& Mean & $N$ & $\begin{array}{l}\text { Standard Deviation } \\
\text { (S.D) }\end{array}$ \\
Posttest & 15.230 & 15 & 2.773 \\
Pretest & 3.230 & 15 & 2.242 \\
\hline \hline
\end{tabular}

In Table III, the mean of pretest is 3.230 and posttest is 15.230 for the graphic animation composition topic. This represents a positive improvement from pretest result of $($ mean $=3.230$, S.D $=2.242, n=15)$ to posttest of (mean $=$ 15.230, S.D $=2.773, n=15$ ). The results show significant achievement after using the graphic design learning module.

TABLE IV: DESCRIPTIVE STATISTIC, MEAN ANDSTANDARD DEVIATIONON PRETEST AND POSTTEST TO MAKING GRAPHIC ANIMATION

\begin{tabular}{llll}
\hline \hline & Mean & $N$ & $\begin{array}{l}\text { Standard Deviation } \\
\text { (S.D) }\end{array}$ \\
Posttest & 16.462 & 15 & 2.025 \\
Prestest & 3.846 & 15 & 2.230 \\
\hline \hline
\end{tabular}

Table IV shows mean of pretest is 3.846 and posttest is 16.462 for the making graphic animation topic This represents a positive improvement from pretest result (mean $=$ $3.846, \mathrm{~S} . \mathrm{D}=2.230, n=15)$ to posttest of (mean=16.462, S.D $=2.025, n=15)$. The results show significant achievement after using the graphic design learning module.

TABLE V: DESCRIPTIVE STATISTIC, MEAN AND STANDARD DEVIATIONFOR PRETEST AND POSTTEST ON GRAPHIC ANIMATION DOCUMENTATION

\begin{tabular}{llll}
\hline \hline & Mean & $N$ & $\begin{array}{l}\text { Standard Deviation } \\
\text { (S.D) }\end{array}$ \\
Posttest & 19.539 & 15 & 2.184 \\
Pretest & 3.846 & 15 & 2.076 \\
\hline \hline
\end{tabular}

Statistic analysis on Table V shows mean of pretest is 3.846 and posttest is 19.539 for graphic animation documentation topic. This represents a positive improvement from pretest result $($ mean $=3.846$, S.D $=2.076, n=15)$ to posttest of (mean $=19.539$, S.D $=2.184, n=15)$. The results show significant achievement after the deaf students use the graphic design learning module.

TABLE VI: DescriPtive Statistic, MEAn AND Standard DEVIATIONFor PRETEST AND POSTTEST ON ALL TOPICS

\begin{tabular}{llll}
\hline \hline & Min & $n$ & $\begin{array}{l}\text { Sisihan Piawaian } \\
\text { (S.D) }\end{array}$ \\
& & & 2.832 \\
Posttest & 78.15 & 15 & 1.989 \\
Pretest & 15.54 & 15 & \\
\hline \hline
\end{tabular}

Table VI shows mean different of pretest and posttest is 15.54 and 78.15 for all topic. This indicates a positive increment for all topic from the pretest results of (mean = $15.54, \mathrm{~S} . \mathrm{D}=1.989, n=15)$ to posttest of (mean=78.15, S.D = $2.832, n=15$ ). The results show significant achievement after using the graphic design module based on technology and deaf learning styles for all topics.

In Table VII, mean score between pretest and posttest for all topics shows significant different. It was proven when $\mathrm{p}$ value is .000 which less then .05 ( $p<.05)$. In Addition, 95\% 
different confident interval $(59.851,65380),(11.221,13.394)$, $(11.145,12.855),(11.470,13.760)$ and $(11.994,15.391)$ shows pretest and posttest have significant different when posttest shows deaf students achievement increased. However, comparative mean for each topic shows introduction of graphic animation has lower mean value which is 11.538 compared to others topic while graphic animation documentation indicate higher mean value of 13.692. This is because the first topic involves memory on history such date, place, terms compared to other topics which emphasize on practical questions. These finding approved the findings of previous research conducted by [16], [27], which indicated that deaf students have low memory capability especially to remember date, place and sequence. Specifically, the introduction of graphic animation topic contains historical information regarding the animation origins. This topic also includes classical terms that share almost identical definition and thus, might cause confusion among deaf students. On the other hand, Topic 4 has the second higher mean value 12.615, and S.D $=1.895, n=15$ ) followed by second and third topic that have mean value $=12.308$, and S.D $=1.797, n=15)$ and $($ mean $=12.000$, S.D $=1.414, n=15)$.

TABLE VII: PAIRED SAMPLE T TEST FOR PRETEST AND POSTTEST ON All TOPICS

\begin{tabular}{|c|c|c|c|c|c|c|}
\hline & \multicolumn{6}{|c|}{$\begin{array}{l}\text { Paired Sample t Test } \\
\quad 95 \% \text { DifferentConfident Interval }\end{array}$} \\
\hline & Mean & (S.D) & Lower & Upper & $t$ & Sig. $(2-$ Tailed $)$ \\
\hline $\begin{array}{l}\text { Topic } 1 . \\
\text { Posttest-Pretest }\end{array}$ & 11.538 & 2.184 & 10.219 & 12.858 & 19.06 & .000 \\
\hline $\begin{array}{l}\text { Topic } 2 . \\
\text { Posttest-Pretest }\end{array}$ & 12.308 & 1.797 & 11.221 & 13.394 & 24.69 & .000 \\
\hline $\begin{array}{l}\text { Topic } 3 \text {. } \\
\text { Posttest-Pretest }\end{array}$ & 12.000 & 1.414 & 11.145 & 12.855 & 30.59 & .000 \\
\hline $\begin{array}{l}\text { Topic } 4 . \\
\text { Posttest-Pretest }\end{array}$ & 12.615 & 1.895 & 11.470 & 13.760 & 24.00 & .000 \\
\hline $\begin{array}{l}\text { Topic } 5 . \\
\text { Posttest-Pretest }\end{array}$ & 13.692 & 2.810 & 11.994 & 15.391 & 17.57 & .000 \\
\hline
\end{tabular}

TABLE VIII: ONE SAMPLE T TEST ON ALL TOPICS

\begin{tabular}{lccc}
\hline \hline & One Sample t Test & Sig. (2-Tailed) & 10.462 \\
\hline $\begin{array}{l}\text { Introduction of Graphic } \\
\text { Animation }\end{array}$ & $t$ & .000 & \\
$\begin{array}{l}\text { Graphic Animation } \\
\text { Framework }\end{array}$ & 10.290 & .000 & 15.846 \\
$\begin{array}{l}\text { Graphic Animation } \\
\text { Compisition }\end{array}$ & 16.511 & .000 & 16.154 \\
Making Graphic Animation & 15.867 & .000 & 16.923 \\
$\begin{array}{l}\text { Graphic Animation } \\
\text { Documentaion }\end{array}$ & 15.714 & .000 & 17.385 \\
\hline \hline
\end{tabular}

\section{Normality Test for Posttest}

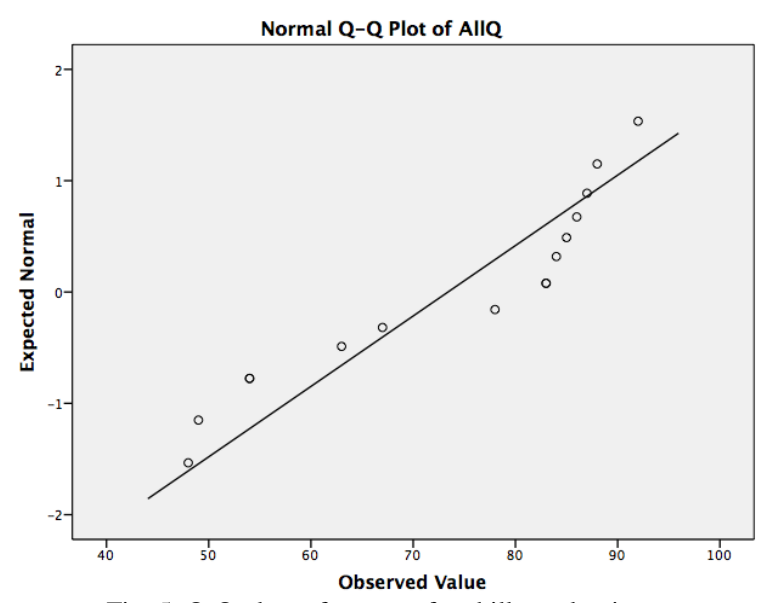

Fig. 5. Q-Q plots of posttest for skills evaluation.

Normality testing was run to ensure the data was normally distributed. The findings showed $p<.05$ and is significant [25], [26] and are normal with Skewness -0.589 (SE = 0.580) and Kurtosis $-1.410(\mathrm{SE}=1.121)$. The $\mathrm{z}$-scores value indicate confident intervals in the range of $(-1.96 \leq z \geq 1.96)$. Below
Fig. 5 are Q-Q plots for the posttest on skills.

\section{Posttest on Skills Evaluation}

Besides pretest and posttest on deaf comprehension evaluation, researcher also conducted a posttest on the skills evaluation from five different topics. One sample $t$ test was used to map the difference in achievement from the assignment given.

In Table VIII, sample $(n=15)$ shows an achievement in introduction of graphic animation, graphic animation framework, graphic animation composition, making graphic animation and graphic animation documentation. Findings showed significant improvement in all topic, but graphic animation documentation has the highest mean and is significant, where $t=23.822$. Topic 5 is the least topic provided in this graphic design learning module and it showed that the deaf students mastery comprehension and skills. Topic 4 remained as second higher achievement with significant value of (mean $=16.923, p<.05)$. Next, topic 3 also achieved significant value of $($ mean $=16.154, p<.05)$ as well as topic 2 with significant value of (mean $=15.846, p$ $<.05)$. Topics 1 remained as the lower rank on the deaf skills achievement. 


\section{CONCLUSION}

In conclusion, parametric evaluation shows pretest and posttest on comprehension and skills towards 15 deaf students for all topics have significant different after using graphic design module based on technology and deaf students learning styles. In addition, statistics analysis showed comprehension and skills were significantly different. Topic 1 recorded lower significant difference for both comprehension and skills results compared to others topics. Even though the deaf students used graphic design module based on technology and learning styles, they were still week in remembering. However, others topics showed similar significant difference for both comprehension and skills. The researchers suggest future research to emphasize on remembering development for topic that involves theory. Also, it is recommended to employ big sample size and to make a comparison to other deaf students' learning context. In turn, it is hoped that these findings will add flesh to research on deaf students in higher education institutions.

\section{ACKNOWLEDGMENT}

The authors wish to thank the Ministry of Education Malaysia as this work was supported in part by a permission on conducting this research to representative vocational school and polytechnic especially deaf students.

\section{REFERENCES}

[1] World Health Organization. (2014). Deafness and hearing loss. [Online]. Available: http://www.who.int/topics/deafness/en/

[2] S. T. Gelfand, Essentials of Audiology, New York, NY; Thieme Medical Publishers, 2009.

[3] Kementerian Pendidikan Malaysia. (2013). Pelan Pembangunan Pendidikan Malaysia. [Online]. Available: http://www.moe.gov.my/v/pelan-pembangunan-pendidikan-malaysia2013-2025

[4] F. J. Harrington, "Sign language interpreters and access for deaf students to university curricula: The ideal and the reality," The Critical Link 2: Interpreters in the Community, vol. 219, 2000.

[5] R. Zaharudin, N. Nordin, and M. H. M. Yasin, "Online ICT-courses integrated for the hearing-impaired individuals' education: A Preliminary study from the students' perception," Communication in Computer and Information Science, pp. 56-63, 2011.

[6] R. Landa, Graphic Design Solution, Clifton Park, New York, United States of America: Thomson, 2006.

[7] O. Selina. Deaf graduates, LimKokWing University, Deaf boleh! Malaysia. [Online]. Available: http://deafboleh.blogspot.my/2012/06/deaf-graduates-2012-limkokwi ng.html

[8] W. Ryan and T. Conover, Graphic Communication Today, Clifton Park, New York, United States of America: Thomson, 2004.

[9] Z. Naimie, S. Siraj, R. Abuzaid, and R. Shagholi, "Did you cook based on the right recipe? (Accommodating the student preferences in class)," Social and Behavioral Sciences, pp. 383-387, 2010.

[10] S. Graf, Kinshuk and T. C. Liu, "Supporting teachers in identifying students' learning styles in learning management systems: An automatic student modelling approach," Educational Technology \& Society, pp. 3-14, 2009.

[11] F.Yang and C. Tsai, "Investigating university student preferences and beliefs about learning in the web-based context," Computer and Education, pp. 1284-1303, 2008.

[12] T. Larkin-Hein and D. Budny, "Research on learning style: Applications in physics and engineering classroom," Education, vol. 44, pp. 276-281, 2001.

[13] H. Knoors and M. Marschark, Teaching Deaf Learners, New York: Oxford University Press, 2014.

[14] M. Stinson and T. Kluwin, "Educational consequences of alternative school placement," The Oxford Handbook of the Deaf Studies, Language, and Education, New York: Oxford University Press, vol. 1, pp. 47-62, 2011.
[15] M. Lim, "My slang-an electronic Malaysian sign language dictionary," MA. disertation, Dept. Comp. Sci. \& Tech., Malaya Univ. Malaysia, 2008.

[16] M. L. Hall and D. Bavelier, "Working memory, daefness, and sign language," The Oxford Handbook of Deaf Studies, Language, and Education, vol. 2, pp. 458-471, New York, NY: Oxford University Press, 2010.

[17] E. Lichtenstein, "The relationships between reading processes and English skills of deaf college students," Journal of Deaf Studies and Deaf Education, vol. 3, pp. 80-134, 1998.

[18] R. Pintner and D. Patterson, "A comparison of deaf and hearing children in visual memory for digits," Journal of Experimentl Psychology, vol. 2, pp. 76-88, 1917.

[19] A. Isman, F. A. Banmy, H. B. Hussein, and M. A. Al-Saadany, "Effectiveness of instructional design model (ISMAN-2011) in developing the planning teaching skills of teachers college students' at King Saud University," The Turkish Online Journal of Educational Technology, vol. 11, issue 1, 2012.

[20] R. Gagne, The Conditions of Learning, New York: Holt, Rinehart \& Winston, 1985.

[21] M. Silver, Exploring Interface Design. Proven Techniques for Creating Compelling \& Usable Interfaces for Multimedia \& the Web, Thomson Delmar Learning, Clifton Park, NY, 2005, pp. 50-52.

[22] J. M. Spector, Foundations of Educational Technology, New York: Routledge, 2012, pp. 81-82.

[23] L. N. Leech, C. K. Barret, and A. G. Morgan, IBM SPSS for Intermediate Statistic: Use and Interpretation, Routledge, NY, 2011.

[24] W. Dick, L. Carey, and O. J. Carey, The Systematic Design of Instruction, Pearson, New Jersey, 2009.

[25] N. M. Razali, and Y. B. Wah, "Power comparison of Shapiro-Wilk, Kolmogrov-Shmirnov, Lilliefors and Anderson-darling test," Journal of Statistical Modelling and Analytics, vol. 2, no. 1, pp. 21-33, 2011.

[26] S. S. Shapiro and M. B. Wilk, "An analysis of variance test for normality (complete sample)," Biometrika, vol. 52, no. 3/4, pp. 591-611, 1965.

[27] H. Hamilton, "Memory skills of deaf learners: Implications and applications," American Annals of the Deaf, vol. 156, no. 4, pp. 402-423, 2011.

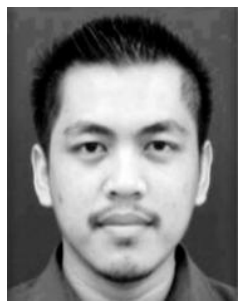

Zainuddin Ibrahim is from Kuala Lumpur, Malaysia, and was born on May 13, 1980. He obtained his master's degree in visual communication \& new media in Universiti Teknologi MARA, Shah Alam, Malaysia in 2008.

He is currently a lecturer at Graphic Design and Digital Media Department, Art and Design Faculty, Universiti Teknologi MARA for 11 years since 2004 . He was appointed as e-learning fellow for the university since 2006. He has industrial working experiences for 2 years in advertising agency as graphic designer before joining the university.

Mr. Zainuddn Ibrahim is also a member of Malaysian Qualification Agency since 2006. He has evaluated almost 20 programs in the field of graphic design and multimedia from variouslocal and international academic institutions regarding program acreditation. He won gold medal in innovation design competition 2008 and 2012 on creating elearning platform for students on mobile.

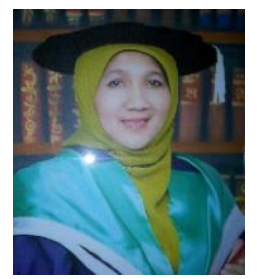

Norlidah Alias has obatined her Ph.D in curriculum design and development from the University of Malaya in 2010.

She is a senior lecturer at the Department of Curriculum and Instructional Technology, Faculty of Education, University of Malaya, Kuala Lumpur, Malaysia. She actively researches and publishes in the areas of pedagogical module based on technology and learning styles, homeschooling, collaborative mobile learning and Gerontology. She is especially known for her pedagogical module based on technology and learning styles which has reframed current ways of teaching abstract Science Concepts by matching learning styles with technology. Her homeschooling research is the first of its kind in Malaysia. Her works are published in top tier Malaysian and International journals including Journal of Educational Tehnology and Society (ETS), Eurasian Journal Mathematics, Science and Educational Technology (EJMSET), Educational Technology Research \& Development (ETR\&D) and The Turkish Online Journal of Educational Technology (TOJET). She has also published books on Pedagogical Module based on Technology and Learning Styles, Pendidikan Alternatif Homeschooling, Design and Developmental Research: An 
Emergent Trend in Educational Research and Kurikulum: Satu Disiplin yang Dinamik.

Dr. Norlidah has received recognition for her teaching and research including awards such as University of Malaya's Excellent Service Award 2014, Univerity of Malaya Excellent Service Certificate 2013 and honorarium for finishing her Ph.D in less than three years. She has also won the Gold Medal Award 2010 at the International Invention, Innovation and Technology Exhibition (ITEX) held in Malaysia. She is the honorary Secretary of the Persatuan Kurikulum Malaysia (PerKum). She has wide experience in teaching and training in the area of Curriculum and educational technology. She also serves as Editor of Malaysian Online Journal of Educational Technology (MOJET) and Jurnal Kurikulum dan Pengajaran Asia Pasifik (JuKu). She is an International Board Member of TOJET and a reviewer for ETS. She is currently involved in various trans-disciplinary national and international collaborative research projects including a high impact longitudinal research (MELOR) and Knowledge Transfer Programme with FELDA Science Learning Centre and Teacher Training Institution, as well as homeshooling Research with well-known collaborators in the USA and Indonesia. She also has an International Post Doctoral Research Fellow attached under her project.

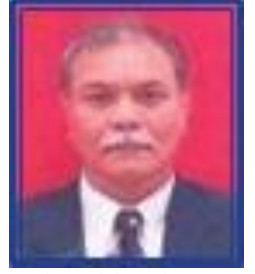

Abu Bakar Nordin obtained his Ph.D in testing, measurement and evaluation, University of Chicago, Chicago, in1989.

$\mathrm{He}$ is an emeritus professor and senior research fellow at the Department of Curriculum and Instructional Tecnology, Faculty of Education, University of Malaya. He has large contribution in servicing most Famous Malaysian University such Universiti Kebangsaan Malaysia (UKM), Universiti Sains Malaysia (USM) and Universiti Pendidikan Sultan Idris (UPSI)

Dr. Abu Bakar Nordin is the member of Malaysian Qualification Agency since 2009. He recieved mutiple awards from Malaysian Examination Board as a Examition Board Figure. His intelectual contribution cover areas such as, Measuring of Marco Educational Environment for Sport, Copyright, 23 April 2008. He is also the Chairman of PEMADAM (Preventing Drug Malaysian Association) from 2008 to 2012. 